\title{
MIGRATION CARRIER-STUDY OF VOJVODINA HUNGARIAN YOUNG ECONOMISTS AND ENGINEERS
}

\section{MIGRÁCIÓS KARRIERKÖVETÉSI VIZSGÁLATOK A VAJDASÁGI MAGYAR FIATAL KÖZGAZDÁSZOK ÉS MÉRNÖKÖK KÖRÉBEN}

\author{
Éva Szügyi, Ph.D. hallgató \\ Pécsi Regionális Politika és Gazdaságtan Doktori Iskola, \\ Pécsi Tudományegyetem, Közgazdaságtudományi Kar \\ Regionális Tudományi Társaság Szabadka. \\ Adress: $\quad 24430$ Ada, Szerbia,Đure Đakovića 169/c. \\ Phone: $\quad+38163-8592-451$ \\ E-mail: $\quad$ eva.szugyi@yahoo.com

\section{Zoltán Takács, doktor-jelölt} \\ Pécsi Regionális Politika és Gazdaságtan Doktori Iskola, \\ Pécsi Tudományegyetem, Közgazdaságtudományi Kar \\ Regionális Tudományi Társaság Szabadka. \\ Cím: $\quad 24420$ Magyarkanizsa, Szerbia, Sumádia utca 31. \\ Tel: $\quad+38163-16-19-118$ \\ E-mail: $\quad$ takac.zoltan@gmail.com
}




\title{
MIGRATION CARRIER-STUDY OF VOJVODINA HUNGARIAN YOUNG ECONOMISTS AND ENGINEERS
}

\author{
MIGRÁCIÓS KARRIERKÖVETÉSI VIZSGÁLATOK A VAJDASÁGI \\ MAGYAR FIATAL KÖZGZDÁSZOK ÉS MÉRNÖKÖK KÖRÉBEN
}

\begin{abstract}
Kivonat
A vajdasági magyar fiatal értelmiség fontos alkotó elemét képezi a Szerbiában élő magyar nemzeti közösségnek. A Szerbia és Magyarországok között zajló népességmozgás egyik karakteres csoportja a tanulómigráló-ingázó fiatalság, amely föképp az elmúlt 10-12 évben egyre gyakrabban dönt a Magyarországon tanulás mellett. Elvándorlásukkal, tartós kitelepülésükkel a nemzeti közösség szenved maradandó károkat (agyelszívás, társadalmi pozícióvesztés, biológiai-reproduktív és demográfiai veszteségek). A tanulmány a vajdasági magyar fiatal egyetemisták és diplomások tanulási célú karrierkövetését elemzi. A mintába (szociológiai mélyinterjúk, 2010 - 24-34 éves fiatal diplomás közgazdászok, mérnökök, illetve egyetemiföiskolai hallgatók) olyan személyek kerültek, akik tanulmányukat a két országban (Szerbiában és Magyarországon) végzik/végezték. Állandó - transznacionális jellegü kapcsolatokkal rendelkeznek. Mégis, (a legfontosabb momentum) hogy tanulmányuk befejeztével (vagy jövöbeli befejezését követöen) hazatértek/hazatérnek Szülöföldjükre, hosszú távú boldogulásukat és szakmai érvényesülésüket nem a Magyarországra történö emigrációban látják.

Az empirikus kutatás célja volt kísérletet tenni a következő kérdések megválaszolására: Miért választ az elmúlt 20 évben egyre több vajdasági magyar fiatal magyarországi felsőoktatási intézményt felsőfokú képzettség megszerzéséhez? Milyen körülmények szükségesek ahhoz, hogy a külföldön diplomázott hallgatók, a külföldön megszerzett tudással hazatérjenek? Aki Szerbiában tanul tovább, milyen érvekkel támasztja alá döntését? Mennyire erős és milyen emigrációs motivációval rendelkeznek a vajdasági magyar fiatalok?

A tanulási célú migráció mindennapi jelenség a határrégióban (Szeged-Szabadka felsőoktatási vonzáskörzete). A felsőoktatási kínálat, anyanyelv és környezetnyelv, a tanulmányok költségei, a minőségi oktatás mind szerepet játszanak a vajdasági magyar fiatalok iskolaválasztási preferenciáiban. A fiatal diplomások hazatérése sajnos bizonytalan (munkaerö-piaci motívumok, honosítás, a diploma fogadtatása, a környezetnyelv ismerete, stb.). A fiatalok a Szülöföld érzelmi megélése mellett (család, barátok) erős egzisztenciális feltételekkel kalkulálnak, a demokratikus változások, valamint a kedvező társadalom-gazdasági feltételek pedig további reményt adnak a hazatéréshez.
\end{abstract}

Kulcsszavak: felsőoktatás, tanulási célú migráció Szerbia és Magyarország között, emigráció és visszatérés.

\section{Extended Abstract}

Keywords: higher education, migration processes for educational purposes between Hungary and Serbia, emigration or return migration

The number of autochthon Hungarian inhabitants in Vojvodina has significantly fallen, and their identity and regional self-organisation have also become weaker. Emigration is among the processes that have contributed to demographic decline of the national group. Vojvodina Hungarians with Serbian citizenship have moved to Hungary in great quantities for the past 20 years. Their migration was motivated by political factors, the warlike situation. A characteristic group of this population movement is the learning-migrating-commuting youth that has more and more often decided for studying in Hungary, especially for the past 10-12 years.

Young Vojvodina Hungarian intellectuals are important members of the Hungarian national community living in Serbia. With their emigration the national community suffers enduring damages (brain drain, loss of social status, biological-reproductive and demographic losses). This paper analyses the educational career path of young Vojvodina Hungarian students and graduates. Such individuals have been included in the sample who are/have been studying in the two countries (Serbia and Hungary). They have permanent relationships with transnational character. Though, the most important circumstance is that after 
finishing their studies they have returned/will return to their homeland. They do not consider that their longterm prosperity and professional success depends on emigration to Hungary.

Concerning the methodology, some sociological depth interviews were done with 18 people graduates, university and college students - in 2010. The interviewees were such Hungarian young people between 24-34 who are attending/have attended economics or engineering studies in Serbia or Hungary. Two segments have been chosen because, on the one hand, these are among the most preferred professions, and on the other hand, in the case of both branches in Vojvodina these studies are organised partly (economics) or entirely (engineering) in Hungarian teaching language. The selection of interviewees was random, within the predetermined parameters. The difference in genders (12 men, 6 women) can be explained with the fact that mostly men are those who choose engineering training. Territorial distribution of the interviewees: Bečej, Mol, Ada, Senta, Kanjiža, Subotica, Palić. Hungarian towns concerned in migration for educational purposes are: Szeged, Pécs, Budapest.

The goal of the empirical research was to answer/to attempt to clarify the following questions:

- Why have more and more young Vojvodina Hungarians chosen higher educational institutions from Hungary for achieving higher qualifications for the past 20 years?

- What circumstances are necessary for providing that students who have graduated abroad may be willing to return home with their knowledge achieved abroad?

- What are the arguments of those who study in Serbia for doing so?

- How strong and what kind of emigration motivation do young Vojvodina Hungarians have?

The commuting students learning in Hungary begin their university/college studies (rarely even the secondary school) in the "foreign country". After the wars have finished and the period of expressed political and social doubtfulness have passed, the phenomenon and tendency of studying abroad have not fallen into the background. Migration for learning purposes is a significant and everyday phenomenon in the border region (a typical example is the Szeged-Subotica relation). The choice of profession of young Vojvodina Hungarians is decisively influenced by the possibility of learning in mother tongue primarily, followed by material reasons (schooling fee, travel costs, distance etc.). The role of Hungary and the Hungarian higher education manifests in quality education (various offer, attractive fields of study, labour-market motives, diploma issued in EU, evolving individual interests).

The conditions of studying (higher education) in the homeland - considering other career prospects as well - are still not provided for young Vojvodina Hungarians. It is among others affected by recently emerging nationalism, isolating efforts, turning inward, seeking for cultural values and roots among the national group, neglecting the language of the environment (Serbian). In Serbia young people primarily choose profession in the fields of economics, technical studies or pedagogy (because training is partly or entirely organised in Hungarian teaching language), which decision is also influenced by distance from the family. This fact also proves explicit rural mentality of Hungarians.

Almost all of the interviewees graduating in Hungary have returned home, and even those who "remained abroad" have not refused the possibility of settling in Vojvodina. The cause of it lies in strong devotion to family, friends and the homeland itself. In case of migration the target country is Hungary in the first place, the reason for which - beside language and cultural factors - is in the smallest possible distance (especially in the towns of the border region). The willingness to migration could be strengthened by worsening economic and political situation in Serbia. The respondents are ready to move to abroad temporarily in order to achieve professional experience, improve their knowledge and language skills, widen their horizon and gain new ideas.

Staying - remaining in Serbia resulted in strong emotional relations. Public spirit is strong, decades of interdependence and collective culture implied close ties. This has also influenced those who have returned home after finishing their studies in Hungary, and this keeps at home those who have studied in Serbia. Still young people do not return home in many cases (according to some estimation between 30-50\%). With their emigration the national community suffers enduring damages (brain drain, loss of social status, biologicalreproductive and demographic losses). Studying in the homeland (with adequate innovative, cross-border organisations, institutionalisation of multiethnic higher education) could probably stabilise the remaining of the national group in Serbia. 


\section{BEVEZETO $^{5}$}

Szerbia egyetlen autonóm tartománya a Vajdaság Autonóm Tartomány, amely a történelmi változásokat követően is, mind a mai napig megőrizte multietnikus lakossági összetételét. Európa egyik olyan régiója, ahol mintegy harminc különböző autochton nemzeti kisebbség/etnikai közösség él együtt. Az államalkotó nemzet (szerb) képviselőit követően, a legnépesebb etnikai közösség a magyar etnikum. Számuk a 2002-es népszámlálás adatai alapján 290.207 (Vajdaság: 2.024.487). A magyar nemzeti közösség demográfiai kapacitásai hanyatlóak: 1961: 442.561, 1981: 385.356. 2002: 290.207. Az utóbbi 15 évben a délvidéki magyarok száma mintegy 50.000-rel csökkent (Gábrity Molnár,2003, 2006a, 2008a, Penev et al., 2007).

A kisebbségi lét viszontagságai, sok esetben folyamatos asszimilációt, demográfiai gyengülést (elöregedés) és emigrációt eredményezett. A magyar nép alapvető jellemzője a rurális beállítottság, a Szülőföldön való érvényesülés minduntalan keresése. A kulturális- és nemzeti identitás megőrzéséréért tett folyamatos erőfeszítések közepette - az elmúlt húsz évben felerősödő nacionalizmus és társadalom-politikai nyomás alatt - a vajdasági magyarság élettere mára a Tisza mentére és néhány szórványtelepülésre szűkült. A nemzeti közösség oktatása (magyar iskolák) középiskolai szintig megoldott. A vajdasági felsőoktatás nem biztosít megfelelő (és kielégítő) lehetőségeket a magyar fiatalok számára (Gábrity Molnár, 2003a, 2003b, 2005, 2006b, 2007, 2008c, Takács, 2008, 2009).

A Kelet- Közép Európában lejátszódó politikai és társadalmi változások, szerb belpolitikai viszályok (háborúk, embargó, bombázás, erősödő nacionalizmus, stb.) - a határok „mentális felszámolásával”, majd a fizikai korlátok (könnyített magyar állampolgárság) eltörlésével - a vajdasági magyar feltörekvő értelmiség Magyarország felé történő fordulását eredményezték (Nađ, 2006, Gábrity Molnár, 2006a, 2008a, 2008b, Korhecz, 2009). Összegezve: (1.) a felsőoktatás (nemzeti közösség szempontjából) biztosított feltételei Szerbiában, valamint (2.) a Szerbiában lezajlott negatív társadalmi (politikai és erkölcsi) átrendeződések- aktivizálták a határrégió lakosságának mozgását ösztönözték az emigrációt.

\footnotetext{
${ }^{5}$ A tanulmány anyaga konferencia-előadásként hangzott el: "Student mobility or emigration flow? The case of commuting students from Serbia towards Hungary (Zoltan Takac). Border Regions in Transition (BRIT) XI. September 6-9, 2011 Geneva, Switzerland/Grenoble, France. Dissemination of research project TRANSMIGSCOPES 2009-2012. A kutatási projekt támogatója a Svájci Nemzeti Tudományos Alap (SNSF Swiss National Science Foundation), a kutatási projekt koodrinátora Prof. Dr. Doris Wastl-Walter, Berni Egyetem, Földrajztudományi Intézet.
} 
A tanulmány primer adatforrások mellett (szociológiai mélyinterjúk) további szakirodalmi feldolgozásokra és néhány statisztikai elemzésre alapoz, a szerb-magyar határrégió tanulási célú migrációs folyamatainak bemutatásához.

\section{VAJDASÁGI MAGYAR FIATALOK SZERBI ÉS MAGYARORSZÁG MIGRÁCIÓS FOLYAMATAIBAN}

Magyarország a szerbiai migránsok érdeklődési körébe az egykori JSZSZK széthullásával kerül. 1988 és 1999 között Magyarországra 155105 menekülő érkezett (Tóth Pál, 2001). A menekültek cca. 30\%-a magyar nemzetiségü volt. Grečić (2001) Magyarországot jelentős etnikai migráció helyszineként említi, szembetűnő folytonossággal és folyamatossággal (Takač-Kinčes, 2010). Az 1991 és 1993 közti időszakot Nagy az értelmiségiek távozásának időszakaként, a Kft.-alakítás, tőkekimenekítés éveiként jellemzi (Nađ, 2006), továbbá a középiskolát végzett munkások és tanulók indulnak útra ebben az időszakban (Tóth Pál, 1997: Idézi: Gábrity Molnár, 2001.).

Magyarország egyik legjelentősebb szerepe a fiatalok oktatásában nyilvánult (és nyilvánul) meg. 1988 és 1994 között (Tóth Pál, 1997) az összes Magyarországon tanuló külföldi 10,3\%-a jugoszláviai magyar volt. Gábrity Molnár (2001) kutatásaiban az 1999/2000-res tanévről tesz említést, amikor is Magyarországon 395 általános iskolás, 676 középiskolás és 600 egyetemista tanult. Az egyetemisták migrációs motivációit T. Mirnics 2001-ben a következőképpen összegezte: elsődleges ok az anyanyelv (az iskoláskorúak szerb nyelvvel kapcsolatos problémái (Nađ, 2006)), színvonal, otthoni rossz életkörülmények.

Szinte kivétel nélkül minden fiatalt foglalkoztat a migráció gondolata, legtöbbjüket a kedvezőbb anyagi körülmények, szakmai lehetőségek. Elképzelt cél-országok sorrendjében Magyarország az első helyen, majd Nyugat-Európa, és a tengerentúl, Ausztrália, Kanada (T. Mirnics, 2001). Magyarország sok esetben a tranzit migránsok országaként (transit migrants) (Grečić, 2001), ill. „ugródeszkaként“ (Nađ, 2006) jelenik meg. Az emberek migrációról kezdenek gondolkodni, amikor tarthatatlannak érzik a stabilitás vesztését önmagukban, környezetükben, a társadalmi intézményi rendben (Mežnarić, S., 2003). Mihailović (2004) az átmeneti időszakot emeli ki, amelyre jellemző a gerontokrácia, önmegsemmisítő közösségi szellem, elvadulás, biológiai fennmaradási harc. A '90-es évek, az ezredforduló, és a lehetséges jövő ,áldozatainak” nevezi ezeket a generációkat. 
Kutatásiban a „katasztrofális társadalmi események”, és azok „társadalmi költségei” differenciáltan jelennek meg az egyes etnikai csoportokhoz való tartozók esetében.

A vajdasági magyar fiatalok „új lehetöséget kapnak a sorstól a külföldön való tanulással”, új „emberbarát közegben”, ahol „ők csak külföldiek”, Magyarországot „,ajándékba”, ,,ideiglenes élőhelyükül kapják”, és „,nem választják”. Azt az országot, ahol az egyetem után „több a lehetőség”, akár „másik, haladó nyugati kultúrába történő továbblépésre is”, megismerve a „dolgok normális, demokratikus menetét”, azzal a tudattal ugyan, hogy a tanulmányok befejezése után „a határon túli magyar fiatalnak kívánatos vagy kötelezö a szülőföldre való visszatérés” (T. Mirnics, 2001). Vágyak szintjén marad ugyanakkor a szerbiai fiatalok tanulási, továbbképzési, szakmai előrehaladási törekvése, akár munkába állása, Szerbiában ugyanis ezt nem tudják elérni (Mihailović, S., 2004). Ennek feltétele a szülőföld „,demokratikus fejlődése”, ,,tolerancia”, „nyitottság”, „,normális életkörülmények”, „munka és megfelelö egzisztenciális lehetöségek”, amelyek képesek lennének eloszlatni „, a menni vagy maradni” kérdést a fiatalok körében (T. Mirnics, 2001). ${ }^{6}$ Mihailović (2004) tanulmányában minden második szerbiai fiatal menne, Európába, ,,és a fejlett világba, önállóan, Szerbia nélkül”! A többiek pedig esetleg Szerbiával Európába, vagy inkább Szerbiával egy időgépbe, vissza az „ünnepelt múltba”.Általános megállapításként: két évtizede a fiatalság csak arra vár, hogy „,diplomázzon és emigráljon.

Az emigrációból származó veszteségeket között Gábrity Molnár (2008b) emberi, anyagi, illetve demográfiai jellegüeket említ, amely következményeképp a „régió erőtlensége, fejlödési lehetőségeinek hiánya” jelenik meg. A szakemberhiány számos további probléma forrása: lassuló gazdasági fejlődés, munkatermelékenység csökkenés, innováció hiánya, technológiai elmaradás, versenyképesség fokozatos vesztése, stb. Mihailović (2004) a fejletlen és tranzíciós országok kifejezetten erős jelenségeként számol be a „brain drain“ jelenségről, amelyet a Balkánon már „brain flight-nek“ neveznek. A '90-es évektől Jugoszláviát mintegy 30000 magasan képzett szakember hagyta el (Grečić, 2001). Gredelj 2006) „tudományos és kutatói gárda újratermelésének“ „az intellektuális tőke szétszóródásának“, Gábrity Molnár (2008b) a „profilok pótolhatatlanságának“ problémáját említi.

Ezzel ellenben a Szülőföld (illetve az értelmiségi elit néhány tagja) elfogult, reméli az emigránsok részleges, vagy teljes visszatérését. Gredelj (2006) kutatásaiban a szakemberek, a szerb intellektuális tőke „virtuális visszatérésének”,,,interaktív virtuális

\footnotetext{
${ }^{6}$ Szociálpszichológiai kutatás során elvégzett elemzések címszavakban történő, a kutatásunk szempontjából fontos eredmények összegzése.
} 
hálózatépitésének” lehetőségeivel foglalkozik. Különböző csoportjaikat különbözteti meg: „reális visszatérök”, „, half-breed”, „, szezonos emigránsok”, „költözö madarak”. Tudásuk, tapasztalati és kapcsolati tőkéjük mozgósítására hívja fel a figyelmet. Ehhez kapcsolódóan Korhecz (2009) az „élhetetlen Szülöföld-képzetet” szeretné eloszlatni az emigránsokban, akik előtt egykori otthonukban új lehetőségek nyílnak meg. Grečić (2001) a rendszer reformátorait látja a potenciális visszatérőkben, illetve mint a „professzionális munka depolitizálásálásának megtestesítőit“, vendégtanárokat, tudományos-kutatómunkát irányító, segítő szereplőket. Két lehetőséget lát a jugoszláv emigránsok által képviselt „szakmai, anyagi potenciál“" kihasználására: a visszatérés (return option), illetve az intellektuális hálózati diaszpóra megoldás (diaspora option, diaspora network).

A Szerbiában élő magyar közösség migrációs vesztesége Kocsis Károly számításai szerint 1948-1991 között 69193 fö volt (Kocsis, 2002: Idézi Gábrity Molnár, 2006a). Az újgenerációs értelmiségi elit „eltünésével” pedig éppen Szerbia ezredfordulós népességmozgásának elemzése során szembesülünk. Fercsik tanulmányában becslésekre hivatkozik, amelyek szerint a Magyarországon felsőfokú végzettséget szerző határon túli fiatalok megközelítőleg 50\%-a nem tér haza (Gödri - Tóth, 2005. Idézi: Fercsik, 2008), így a tanulás, illetve a továbbtanulás valóban egy migrációs csatorna, amely a letelepedés elökészitő szakaszaként is értelmezhető (Fercsik, 2008), esetleges ugródeszka NyugatEurópa felé.

A délvidéki magyar közösség migrációs veszteségének kárpótlásához, illetve a további csökkenés megállításához nélkülözhetetlen a tartós szülőföldön maradás, szülőföldhöz való visszatérés feltételeinek megteremtése. A délvidéki magyarság tanulásicélú migrációja visszafordítható, illetve racionálisan hasznosítható jelenségként kell, hogy tudatosuljon a politikai elit képviselőiben. Az anyaországban tanuló, diplomát-szerző fiatalok visszatérésére, illetve meglévő tapasztalatuk, kapcsolati tőkéjük - transznacionális hálózataik - mobilizálására nagy szükség van a délvidéki magyar helyi-regionális elit egyetemalapítási törekvéseiben. Megfelelő felsőoktatási kínálattal, határon átívelő innovatív tudományszervezési megoldásokkal, anyanyelvü oktatással, továbbá a regionális gazdaságfejlesztés eszköztárával egy délvidéki (multietnikus) egyetem felszámolhatná a tanulási célú migráció, majd emigráció további hullámait. 


\section{A HATÁRRÉGIÓ INGÁZÓ EGYETEMISTÁI}

A határrégió szerepe - immár 20 év távlatából - újradefiniálódik, „posztmodern” értelmezést kap, ahol a társadalmi, kulturális és gazdasági-egyének és csoportok közötti kapcsolatok revitalizálódnak (Langer, 2001). A háborús múlt a szerb-magyar határt védőfalként jelenítette meg, ahol a fiatalok egy nehéz problémákkal küszködő országot hagytak maguk mögött, egy perspektivikusabb és nyugodtabb életkörülményeket és jobb tanulási feltételeket biztosító ország miatt. Magyarország attraktívvá vált a fiatalok számára (Tóth Pál, 2001, Gábrity Molnár, 2001, Fábri, 2008, Fercsik, 2008, L. Rédei, 2009). Az elmúlt időszakban a fiatal ingázó, Magyarországon tanuló, Szerbiában élő egyetemisták mind nagyobb és karakteresebb csoportja rajzolódik ki a határrégióban. A felsőoktatás területén Szeged térformáló szerepe válik egyre szembetűnőbbé (Pál, 2003), újszerü határon átívelő migrációs mozgások és együttmüködések jelennek meg (Gábrity Molnár, 2008b).

2010-ben magyar felsőoktatási intézményekben 1385 szerbiai állampolgárságú hallgató tanult (769 nö). A nappali tagozatos hallgatók száma 1 009. Alapképzésen 905, mesterképzésen 84, osztatlan képzésen 97, szakirányú képzésen 29, doktori képzésen 40 hallgató tanult, míg 230 hallgató egyéb képzési formában vett részt (felsőfokú szakképzés, főiskolai képzés, stb.). A külföldi állampolgárságú hallgatók 7,6\%-át tették ki a szerbiai származású magyar hallgatók, főleg a Délvidék, Tisza-mente, többségében magyar lakta községeiből. A Szülőföldön, az Újvidéki Egyetemen (állami karokon és főiskolákon) összesen 3152 hallgató tanult. Tehát a mintegy 4 500-4700 fös teljes magyar hallgatói kontingens 30-35\%-a tanul Magyarországon (Nemzeti Erőforrás Minisztérium, Magyarország, 2011, APV Pokrajinski sekretarijat za obrazovanje, Vojvodina-Srbija).

A határrégióban a Szegedi Tudományegyetem jelenti a legnagyobb „elszívó erőt”. A felsőoktatási intézményekbe jelentkező szerbiai állampolgárságú hallgatók felvételi adataiból láthatjuk, hogy az érdeklődés nagyon nagy a magyar nyelvü, minőséges oktatás iránt. A jelentkezők száma minden évben magas. Az utóbbi években (2007-2010) mintegy 300 hallgató nyert felvételt, a jelentkezés minden esetben 2-3 szoros (!). 2010-ben 927 tanuló felvételizett, és 293 tanuló nyert felvételt (a Szegedi Tudományegyetem karaira) (Educatio Kht. 2011). A felvettek tudományterületi rangsorában első helyen a bölcsész szakok $(21,5 \%)$, természettudományi szakok $(16,4 \%)$, informatika $(8,2 \%)$, orvos-és egészségtudomány $(20,1 \%)$ és társadalomtudományok (13,3\%) állnak. A tanulók nagyon tudatosan válogatnak a Szerbiában (magyarul) rendelkezésre nem álló képzési lehetőségek 
közül. Tehát a potenciális migrációs veszteség nagy, ugyanis a határ dinamikus tanulási célú mozgást, és későbbi emigrációs csatornát jelent.

A vajdasági magyarok a vizsgált határrégióban (Szeged-Szabadka) majdnem felefele arányban tanulnak itthon és Magyarországon (az elsőéves hallgatók statisztikáit elemezve): ${ }^{7}$

- 30\% Magyarországon (Szeged, Budapest, Pécs, Debrecen),

- 50 \% Hazai állami karokon, részben magyar nyelven (Szabadka-Újvidék),

- 20\% Szabadka környéki magánkarokon.

A migráció (tartós kitelepülés) reális és fennálló veszélye miatt jelentkeznek problémák, ugyanis a régióban maradó fiatalok 1/4-e müszaki végzettségü, 1/4-e tanító, óvónő, 1/4-e közgazdász, menedzser, azaz potenciális diplomás munkanélküli lesz, a felsőfokú képzési rendszerből kilépve! A tanulmány célja elemezni a határrégióban (Magyarország-Szerbia) lezajlódó tanulási (és- részben munkavállalási) migráció jellemzőit, kiemelve a Szerbiába visszatérö fiatal diplomás értelmiség érvényesülési lehetöségeit.

\section{AZ EMPIRIKUS KUTATÁSI EREDMÉNYEK}

A vajdasági magyar fiatal értelmiség fontos alkotó elemét képezi a Szerbiában élő magyar nemzeti közösségnek. Elvándorlásukkal, tartós kitelepülésükkel a nemzeti közösség szenved maradandó károkat (agyelszívás, társadalmi pozícióvesztés, biológiai-reproduktív és demográfiai veszteségek). A tanulmány a vajdasági magyar fiatal egyetemisták és diplomások tanulási célú karrierkövetését elemzi. A mintába olyan személyek kerültek, akik tanulmányukat a két országban (Szerbiában és Magyarországon) végzik/végezték. Állandótransznacionális jellegü kapcsolatokkal rendelkeznek. Mégis, (a legfontosabb momentum) hogy tanulmányuk befejeztével (vagy jövőbeli befejezését követően) hazatértek/hazatérnek Szülőföldjükre, hosszú távú boldogulásukat és szakmai érvényesülésüket nem a Magyarországra történö emigrációban látják.

Módszertanilag szociológiai mélyinterjúk készültek 18 személlyel - diplomással, egyetemi- illetve föiskolai hallgatóval, 2010-ben. Olyan 24-34 éves magyar fiatalokkal készültek interjúk, akik közgazdasági vagy mérnöki ${ }^{8}$ képzésben vesznek/vettek részt Szerbiában vagy Magyarországon. A választás két szegmensre esett, mert, egyrészt a

\footnotetext{
${ }^{7}$ Összehasonlító elemzések: KSH Központi Statisztikai Hivatal (Budapest), Köztársasági Statisztikai Hivatal (Belgrád) (Republički zavod za statistiku Beograd) 2011.

${ }^{8}$ Szerbiában a mérnöki képzés keretein belül történik az informatikai képzés is, ezért a mintába informatikai végzettségü fiatalok is belekerültek.
} 
fiatalok által leginkább preferált szakok közé tartoznak, másrészt Vajdaságban mindkét szak esetében lehetőség van részben (közgazdasági képzés) vagy egészében (mérnöki képzés) magyar nyelven folytatni a tanulmányokat. Az alanyok kiválasztása az előre meghatározott paramétereken belül véletlenszerü volt. A nemek közötti eltérés (férfi 12, nő 6) azzal is magyarázható, hogy a müszaki képzést általában férfiak választják. Az alanyok területi megoszlása: Tisza mente: Óbecse, Mohol, Ada, Zenta, Magyarkanizsa, Szabadka, Palics, valamint Magyarországon a tanulási célú migrációban érintett települések: Szeged, Pécs, Budapest.

Az empirikus kutatás céljavolt megválaszolni/kísérletet tenni a következő kérdések megvilágítására:

- Miért választ az elmúlt 20 évben egyre több vajdasági magyar fiatal magyarországi felsőoktatási intézményt felsőfokú képzettség megszerzéséhez?

- Milyen körülmények szükségesek ahhoz, hogy a külföldön diplomázott hallgatók, a külföldön megszerzett tudással hazatérjenek?

- Aki Szerbiában tanul tovább, milyen érvekkel támasztja alá döntését?

- Mennyire erős és milyen emigrációs motivációval rendelkeznek a vajdasági magyar fiatalok?

A kutatás során felvetett hipotézisek rövid logikai lánca: a tanulási célú migráció jelentős és mindennapi jelenség a határrégióban, a 2000-2008-as időszakban tapasztalt pozitív demokratikus változások reményt adtak a fiataloknak, és többen, tanulmányuk befejeztével hazatértek. A fiatalok a Szülőföld érzelmi megélése mellett erős egzisztenciális feltételekkel kalkulálnak, amikor felsőfokú végzettségüket megszerzik. A diploma (diszciplináris megoszlás) akkor tud a Vajdaságban érvényesülni, ha az környezetnyelvtudással társul. A régióban minden egyetemi végzettségű (visszatérő) magyar fiatal szívesen látott, még abban az esetben is, ha telítődött divatszakmáról van is szó (pl. közgazdász-menedzser képzés).

\section{SZÉLESEDŐ TANULÁSI HORIZONT, TANULÁSI LEHETŐSÉGEK MAGYARORSZÁGON ÉS SZERBIÁBAN}

A mélyinterjúk során bizonyítást nyernek - a fiatalok időszerü iskolaválasztási preferenciái külföldön és itthon, Magyarország populáris felsőoktatása, Szerbia/Vajdaság hiányosságai - a tanulási célú migrációt kiváltó okok és jellegzetes életviteli formák a határrégió fiataljai körében. Az interjúalanyok véleménye alapján megfogalmazhatók azok a 
feltételek, amelyek mellett a vajdasági magyar fiatal értelmiség hajlandó szülőföldjére visszatérni, munkát vállalni, karriert építeni Szerbiában.

A tanulási célú migrációt kiváltó okok - előzmények:

- Abban az időszakban, amikor a migráció (politikai és társadalmi bizonytalanságok, problémák, NATO bombázás) indokolt volt, nehéz (illetve nehezebb volt) a bejutás a különböző felsőoktatási intézményekbe. Kivételt az 1999-es év (tavaszi szemeszter) jelent, ugyanis ekkor a magyarországi felsőoktatási intézmények feltétel nélkül befogadták évfolyamaikra a szerbiai határontúli hallgatókat.

„, Szerbiában '99-ben a helyzet rosszabb volt, mint elötte bármikor, föleg erre felénk, egyáltalán nem láttad azt, hogy jó irányba tartana a dolog. Gimnáziumi tanáraink még a '90-es évek második felében biztattak bennünket, hogy majd jobb lesz, meg minden, de volt olyan tanár, aki a bombázások kezdetének a napján (amikor hazaküldtek bennünket az iskolából), azzal fogadott bennünket, hogy eddig bármit vártunk/várhattunk - ök már tíz éve várják, hogy javuljon itt a helyzet-MENJÜNK, AMERRE LÁTUNK A VILÁGBA, CSAK MINÉL MESSZEBB ETTÖL AZ ORSZÁGTÓL!’. Volt olyan tanárunk, aki a végsőkig tartotta bennünk a lelket, magyar anyanyelvü, de ezzel az évvel szerintem mindenki megkapta a kegyelemdöfést...”(...) „Nincs arra idöm, hogy várjam azt, hogy majd történik valami. Gyakorlatilag ilyen dolgok vezéreltek akkor.” - 29 éves közgazdász, Pécsi Tudományegyetem, Magyarország.

- Az elmúlt 15 évben nagymértékben változott (liberalizálódott) a magyarországi felvételi rendszer (felsőoktatási expanzió, demográfiai űr), és sok esetben a vajdasági magyar hallgatók külföldi tanulmányok mellett döntenek.

A külföldi tanulmányok mellett és ellen szóló érvek:

- Szakmaelsajátítás miatt egyszerűbb anyanyelven tanulni (viszont elhelyezkedés esetében, a Szülöföldön a környezetnyelv ismeretének hiánya abszolút hátrány),

- Minőségi-színvonalas felsőoktatás, színes kínálat, egyszerü megközelítés (pl. Szeged), ösztöndíj-politika (Magyar Állam, Vajdasági Magyar Felsőoktatási Kollégium),

- jobb (anyagi feltételeket biztosító) elhelyezkedési esélyek, akár az Európai Unió országainak munkaerőpiacán is. 
Itthon tanulók által megfogalmazott érvek/ellenérvek:

- tannyelv (teljesen vagy részben magyar) alapján megszületett iskolapreferencia, a személyi indíttatás - érdeklődés elvonatkoztatása (további problémák a környezetnyelvvel),

- közelség, költségek (útiköltség, bentlakás, kedvező tandíj, állami finanszírozás), mint döntő tényező az iskolaválasztás során,

- nagyobb informáltság (ismertek itthon a szabadkai, újvidéki karok)

- a felsőoktatás alacsony minősége, presztízs-vesztése: elavult rendszer, elavult ('70'80-as évekből származó irodalom) módszerek, nagy évfolyamok, hierarchikus tanár-diák viszony, kontraszelektív rendszer.

A megkérdezettek személyes véleménye szerint az intézményválasztást döntően befolyásolja a magyar nyelven történő tanulás lehetősége. Sok esetben a diploma munkaeröpiaci esélyei válnak marginálissá. Ez főként Szerbia esetében igaz, ahol a felsőoktatási kínálat szűkös, míg Magyarország a hallgatók számára nagy lehetőségeket jelent, szakmai téren (egyéni szakmai aspirációk, későbbi munkaerő-piaci perspektívák). Szerbiában fontos, hogy a fiatal „valamilyen” felsőoktatási intézményben tanuljon, mert felsőfokú végzettséggel a „köztudatban - általánosítva” könnyebb elhelyezkedni, és a „továbbtanulás is jobb a munkanélküliségnél” elv érvényesül.

Az egyén érdeklődési körével kapcsolatosan fontos kiemelni (föképp Szerbiára vonatkoztatva), hogy előbb tisztázódik a felsőoktatási intézmény helye és csak azután a konkrét szak. A baráti körnek és részben a szülőknek van meghatározó szerepe a döntés meghozatalában. A tanulmányok költségei tovább optimalizálják a döntést: szempont, hogy az intézmény ne legyen távol a szülővárostól, hiszen így elkerülhető a költséges „bentlakás” az egyetemnek/föiskolának otthont adó városban, illetve ingázás esetén a rövidebb táv alacsonyabb útiköltséggel is jár. Az oktatás minősége külön helyet kap az intézményválasztás során. Ez adhat elsősorban okot a külföldön történő továbbtanulásra.

A két országban megszerzett diploma között különbségeket vélnek felfedezni a munkaerőpiacra bekerülő friss diplomások. Elsődleges megállapítás: közgazdászként nehezebb munkát találni mindkét országban (telitett piac), gyakori a magánvállalkozás és átképzés, továbbképzés, feketemunka. Mérnökként bárhol és bármikor lehet munkát találni. 
A Szerbiában végzettek többnyire (hazai, állami intézmény által kiadott diploma presztízse, szerb nyelv tudása) meg vannak elégedve diplomájukkal. Nem zárkóznak el annak lehetőségétől sem, hogy (esetleges) másoddiplomát Magyarországon szerezzenek. Az viszont tény, hogy a Vajdaságban megszerzett diplomának külföldön csak akkor van értéke, ha konkrét munkahelyen alkalmazható (külkereskedelem, piaci kapcsolatok, idegen nyelv, stb.). A fiatalok számára fontos azonban az Európai Unió szintjén elismert diploma. A Magyarországon végzettek úgy gondolják, hogy magasabb minőségü oktatásban részesültek/részesülnek, mint ha Szerbiában tanultak volna, és nem értenek egyet a honosítás kötelező és hosszadalmas, költséges folyamatával (hosszú várakozási idő, megkülönböztetett bánásmód, egyéntől - adminisztratív munkástól függő különbözeti vizsgaszám, megaláztatások, stb.). Sok esetben az interjúalanyok a hazatérést befolyásoló akadályként említették a diplomahonosítást. Egy állam, amely akár 2 évet is várakoztatja egy Uniós diplomás állampolgár munkaerő-piaci érvényesülését. Ehhez lehet, hogy határozottabb kisebbségi önszerveződési fellépésre, akcióra, lobbira lenne szükség.

(...) „Be kell szerezni a képzési programot, sok forditási költség, időhúzás mellett lefordíttatni. Ezt kidobott pénznek, elvesztegetett időnek tartom”. (...) „Egy világszintü, elismert egyetem által kiadott oklevelet szerintem fölösleges macerálni, hogy az most jó-e vagy nem. Nem hiszem, hogy gyakorlati elemzés történik, és, hogy tényleg összevetik az okleveleket”. - gyakran hallani olyan történeteket is, hogy föiskolát Szerbiában egyetemként honosítanak, mesterképzést pedig megfelelő program hiányában lefele degradálnak, és valójában hátráltatják a hazatérést a 31 éves Ph.D. hallgató (Pécsi Tudományegyetem, Magyarország) véleménye szerint.

\section{A TANULÁSI CÉLÚ MIGRÁCIÓT KÖVETŐ EMIGRÁCIÓ ILLETVE A VISSZATÉRÉS ESÉLYEI A VAJDASÁGI MAGYAR FIATAL DIPLOMÁSOK - KÖZGAZDÁSZOK ÉS MÉRNÖKÖK - KÖRÉBEN}

Vajdaságban az elmúlt háborús, zavargásos két évtized, a gazdasági hanyatlás, majd stagnálás krízisekkel átszőtt időszakában a fiatalok az „elmenni vagy itt maradni” kétségei közt találták magukat. A vizsgált csoport a kivándorlást tanulmányi célokkal kezdeményezte. Későbbi emigrációs szándékaikat munkavállalási okokkal, jobb egzisztenciális perspektívákkal, szakmai továbbfejlődési lehetőségekkel, általános 
biztonságérzettel, stb. indokolják. Mégis, tanulmányaikat követően sokan hazatértek. Példaként szolgálnak ahhoz, hogy a jövőthogyan és milyen feltételek mellett tudják a Szülőföldjükön tervezni.

Az interjúalanyok között szereplő tíz Magyarországon végzett fiatalból heten visszatértek Szerbiába a tanulmányaik végeztével (vagy végéhez közeledve). A Magyarországon munkaviszonyban lévők is nyitva hagyták a hazatérés kérdését.

(...) „Valószínüleg anyagilag kellene, hogy meggyözzenek elsősorban, de sokat számítana az is, hogy milyen körülményeket tudnának biztosítani (munkakörnyezet, társadalmi környezet)”. - 29 éves közgazdász, Pécsi Tudományegyetem, Magyarország.

(...) „Úgy érzem, megtaláltam a helyem itthon, és sajnálnám ezt az egészet, úgymond, a vízbe dobni. Persze ez nem zárja ki azt, hogy esetleg lennének okok, amik útraindítanának... (magasabb bérezés, szakmai tapasztalatszerzés).”- 30 éves informatikai mérnök, Szabadkai Műszaki Szakfőiskola, Szerbia.

Azok, akik hazatértek, tudtak Szerbiában érvényesülni, még ha esetenként kissé csalódottak is - nem annyira a saját lehetőségeik, mint inkább az ország helyzete miatt:

(...) „Terveztem a visszatérést. Akkor azért nagyobb potenciált feltételeztem Szerbiában (2003), mint amennyi ténylegesen van. Elveszett hét év gazdasági fejlödés nélkül. Hát, nem tudom,... nem biztos, hogy jó ötlet volt visszajönni. Nem csalódtam, csak realistább lettem.”- 31 éves Ph.D. hallgató, Pécsi Tudományegyetem, Magyarország.

Egyértelműen erős a szülőföldhöz való kötődés a kérdezettek körében. Ahhoz, hogy külföldre távozzanak azok, akik rendelkeznek Szerbiában is bizonyos szintű egzisztenciával, vagy különösen jó lehetőséget kell, hogy kapjanak külföldön, vagy a hazai helyzet drasztikus romlása kell. A megkérdezettek nagy része Magyarországon rendelkezik még továbbra is ingatlannal, esetleg más transznacionális életformákra utaló szálakkal (vállalkozás, ismerősök, barátok, stb.), amelyek a „két lábon állást”, „,kétlakiságot” tudják megalapozni.

(...),, Gondolkodtam rajta, de nagy motívum kellene, ahhoz, hogy én elmenjek. Tehát ragaszkodom a szülöfalumhoz is elsősorban, a társasághoz, ismerösökhöz. Nehezen 
tudom elképzelni, hogy én elmenjek messzebbre, külföldre, csak a munka miatt.”- 30 éves informatikai mérnök, Szabadkai Müszaki Szakfőiskola, Szerbia.

(...) „Én továbbra is Magyarországon is élek. Elvileg nem élek ott, de ott van továbbra is vállalkozásom, lakásom van, mindenem van. Tehát ha egy nap föl kellene kerekedni és menni, akkor rögtön lehetne menni”. (...) „de, ahhoz nagyon-nagy dolognak kellene történni a világban...(...)”- 33 éves Ph.D. hallgató, Pécsi Tudományegyetem, Magyarország.

A családos fiatalok döntését már párjuk is befolyásolja, hiszen, ha legalább az egyik félnek van megfelelő állása Szerbiában, akkor a másik inkább alkalmazkodik és a maradás mellett döntenek. Ha mégis szó lenne az elvándorlásról, más lehetőség hiányában, akkor Vajdasághoz minél közelebb szeretnének letelepedni, például Dél-Magyarország mellett döntenek, vagy elmennének valamely nyugat-európai országba is, de csak meghatározott időre (tapasztalatszerzésre, nyelvtudásuk tökéletesítésére), aztán a kapott többlettudást Szerbiában kamatoztatnák.

(...) „, Miért szeretnék külföldre menni? Nem is tudom... Kimennék, amíg fiatal vagyok, hogy megnézzem, hogyan müködnek ott a dolgok, tapasztalatot szeretnék szerezni. Esetleg lehet, hogy látok olyasmit, amit haza tudok hozni (tudást, gyakorlatot, tapasztalatot, üzletet, stb.)” - 29 éves közgazdász, Újvidéki Egyetem, Szerbia.

Vannak azonban fiatalok, akik komolyan foglalkoztak az elvándorlás gondolatával, mérlegelték a lehetôségeiket és a migráció reális alternatívaként szerepel a jövőre vonatkozó terveiket illetően.

(...) „Valahova nyugatabbra mennék: Nyugat-Európába, Írországba, talán Angliába.”-31 éves mérnök, Budapesti Műszaki Egyetem, Magyarország. Mások Belgiumot, Svájcot említették, mint attraktív multietnikus közeget.

Mivel a migráció hatalmas méreteket öltött Vajdaságban az elmúlt évtizedekben, minden megkérdezettnek akadnak ismerősei, rokonai, barátai külföldön - szinte kivétel nélkül. Ezek az ismerősök által egy relatív tiszta (nem elfogult, objektív) képet kaphatnak a fiatalok a megélhetésről, az életszínvonalról, lehetőségekről „,ezekben” a külföldi országokban. Azonban az általam vizsgált szegmens legkevésbé erre a kérdésre volt érzékeny. Az eltávozottak sikerei kevésbé vonzóak, mint az itthoni környezet. A magasabb migrációs hajlam ettől függetlenül van meg, vagy hiányzik a fiatalokból. 
(...) „Szeretem ezt az itteni életet, van család, ház, nem vagyok annyira nagyravágyó”

(...). Ha van egy autóm, amibe befér a család, akkor nem kell most egy háromszor akkora autó. Tehát nincs rá szükségem, úgy érzem. Nem, nem vágyok külföldre. Jó ez a nyugalom nekem itt, kisvárosban.” (...) - 31 éves számítástechnikai mérnök, Újvidéki Egyetem, Szerbia.

A családtól és a szerbiai barátoktól való elszakadás már valamivel érzékenyebb téma volt, ugyanígy a szülőföldhöz való ragaszkodás. A megkérdezettek közt voltak, akik a család, barátok biztonságát nem tartották befolyásoló tényezőnek, voltak viszont, akiknél ez a döntő az elvándorlás kérdésében.

(...) „, Manapság már a technológia annyira fejlett, hogy mindenféleképp el tudjuk érni egymást és, ha valakivel akarsz beszélgetni, akkor nem kell várni. Megesik, hogy itthon sem látom öket, csak egy évben egyszer (család, rokonok).” - 25 éves közgazdász hölgy, Újvidéki Egyetem, Szerbia.Többen - akik mobilisek - ugyanígy vélekedtek, és a családot nem tartják ,megkötő erőnek” manapság.

Egy informatikai mérnök elmondása szerint, már több alaklommal is kapott magyarországi állásajánlatot olyan cégnél, aholtöbb ismerőse is dolgozik. Az informatikusok, programozók iránti kereslet a nyugati országokban is magas. Ő mégis az itthon maradás mellett döntött:

(...) „Hívnának ki. Budapeströl 3-4 alkalommal fölkerestek”. (...) „Ez egy hatalmas multinacionális cég, „, nyakkendős munkahely”, jó fizetés”. (...) „Ismerőseim többször hívtak ki, hogy ök biztosan tudják, hogy engem ott ezzel a tudással kapásból fölvennének”. (...) „Én látom rajtuk, hogy annyira nem érzik jól magukat Pesten, magát Budapestet nem szeretik, viszont jól keresnek. Hacsak tehetik, akkor menekülnek ide haza hétvégenként (Tisza-part, nyugalom, pecázás, vadászat...)” (...)

\section{KÖVETKEZTETÉSEK}

A Vajdaságban őshonos magyar nemzeti közösség lélekszáma az elmúlt évtizedek alatt jelentősen csökkent, identitástudata, regionális önszerveződése is meggyengült. A nemzeti közösség demográfiai hanyatlását felerősítő folyamatok között szerepel az elvándorlás is. Az elmúlt 20 évben tömegesen települtek át szerb állampolgárságú vajdasági magyarok Magyarországra. Az elvándorlást politikai motívumok, kényszerű háborús helyzet hozta felszínre. A népességmozgás egyik karakteres csoportja a tanuló-migráló-ingázó 
fiatalság, amely fóképp az elmúlt 10-12 évben egyre gyakrabban dönt a Magyarországon tanulás mellett.

A Magyarországon tanuló ingázó fiatalok főiskolai/egyetemi (ritkább esetben már középiskolai) tanulmányaikat kezdik meg „az idegen országban”. A háborús helyzet, a kifejezett politikai és társadalmi bizonytalanság időszakának lecsitulásával, a külföldön tanulás jelensége és tendenciája továbbra sem került háttérbe. A tanulási célú migráció jelentős és mindennapi jelenség a határrégióban (tipikus példa Szeged-Szabadka reláció). A vajdasági magyarok fiatalok szakválasztását döntően elsősorban az anyanyelven történő tanulás lehetősége befolyásolja, ezt az anyagi okok követik (tandíj, útiköltség, távolság, stb.). Magyarország és a magyar felsőoktatás szerepe a minőségi oktatásban (gazdag kínálat, attraktív szakok-szakpárok, munkaerő-piaci motívumok, EU-s oklevél, egyéni érdeklődés kibontakoztatása) nyilvánul meg.

A Szülőföldön tanulás feltételei (felsőfokon) - más karrierkövetési szempontokat is figyelembe véve -továbbra sem biztosított a vajdasági magyar fiatal számára. Ebben többek között szerepet játszik az elmúlt időszakban kibontakozó nacionalizmus, a nemzeti közösségek izolálódási törekvése, kényszerü befelé fordulása, kulturális értékeinek, gyökereinek keresése, a környezetnyelv (szerb) hanyagolása. Szerbiában tanítói, közgazdasági és műszaki pályákra állnak leginkább a fiatalok (részleges vagy teljes magyar nyelvü képzés miatt), amelyben a családtól való távolság is nagy szerepet játszik. Ezzel is a magyarok kifejezett rurális beállítottsága igazolódik.

A Magyarországon végzett interjúalanyok szinte mindegyike hazatért, és a „kinn maradtak" sem zárkóztak el a Vajdaságban való letelepedés lehetősége elöl. Ennek oka az erős kötődés a családhoz, a barátokhoz és magához a Szülőföldhöz. Migráció esetén a célország elsősorban Magyarország, aminek - a nyelvi-, kulturális tényezőkön kívül - a lehető legkisebb távolságra való távozás az oka (és főleg a határ mente városaiba). Az elvándorlási hajlamot a szerbiai gazdasági-, politikai helyzet romlása tudja erősíteni. A megkérdezettek ideiglenesen vállalnák a külföldön való letelepedést szakmai tapasztalatszerzés, ismeretbővítés, a nyelvtudás fejlesztése, a látókör bővítése, ötletszerzés céljából.

A Szerbiában való maradás - megmaradás szoros érzelmi kapcsolatokat eredményezett. Erős a közösségi szellem, az évtizedek alatti egymásrautaltság, a közösségi kultúra szoros köteléket jelent. Ez befolyásolta a hazatérőket is magyarországi tanulmányaik végeztével, és ez tartja itthon azokat is, akik szerbiai felsőoktatási intézmény 
hallgatói/voltak. Mégis, sok esetben (becslések szerint 30-50\%) a fiatalok nem térnek haza. Elvándorlásukkal, tartós kitelepülésükkel a nemzeti közösség szenved maradandó károkat (agyelszívás, társadalmi pozícióvesztés, biológiai-reproduktív és demográfiai veszteségek). A Szülőföldön tanulás (megfelelő innovatív, határon átívelő tudományszervezés, multietnikus felsőoktatás intézményesítésével) vélhetően stabilizálni tudná a nemzeti közösség megmaradását Szerbiában.

\section{IRODALOM}

Fábri I., 2008. -“Kik tanulnak tovább?”. InFábri Gy. (eds.) Felvételi. Educatio Társadalmi Szolgáltató Kht., Budapest, pp. 91-100.

Fercsik R., 2008. - “Szülőföldről a hazába - és vissza?”. InSzarka L. and Kötél E. (eds.) Határhelyzetek. Külhoni magyar egyetemisták peregrinus stratégiái a 21. század elején. Balassi Intézet Márton Áron Szakkollégium, Budapest, pp. 124-138.

Gábrity Molnár I., 2001. -“A jugoszláviai magyarok vándormozgalmának okai és méretei”. In Gábrity Molnár I. and Mirnics Zs. (eds.) Fészekhagyó vajdaságiak. Magyarságkutató Tudományos Társaság, Szabadka, pp. 115-161.

Gábrity Molnár I., 2003a. -“Az értelmiségpótlás körülményei”. InGábrity Molnár I. and Mirnics Zs. (eds.) Kisebbségi létjelenségek. Magyarságkutató Tudományos Társaság, Szabadka, pp. 287-329.

Gábrity Molnár I., 2003b. -“Anyanyelvű felsőoktatás feltételei a Vajdaságban”.In $A$ vajdasági magyar felsőoktatási konferencia publikációs anyaga. Magyar Nemzeti Tanács, Szabadka.

Gábrity Molnár I., 2005. -“Magyar vagy multietnikus egyetem alapításának indoklása Vajdaságban". In Kontra M. (eds.) Sült galamb? Magyar egyetemi tankönyvpolitika. Forum, Somorja - Dunaszerdahely, pp. 211-228.

Gábrity Molnár I., 2006a. -“Migrációs folyamatok". InGábrity Molnár I. and Ricz A. (eds.) Kistérségek életereje - Délvidéki fejlesztési lehetöségek. Regionális Tudományi Társaság, Szabadka, pp. 69-72.

Gábrity Molnár I., 2006b. - "A vajdasági magyar felsőoktatás szerveződése". InJuhász E. (eds.): Régió és oktatás. Doktoranduszok Kiss Árpád Közhasznú Egyesülete, Debrecen, pp. 105-113.

Gábrity Molnár I., 2007. -"Vajdasági magyar fiatal diplomások karrierje, migrációja, felnőttoktatási igényei".In Mandel K. and Csata Zs. (eds.) Karrierutak vagy parkolópályák? Friss diplomások karrierje, migrációja, felnőttoktatási igényei a Kárpát medencében. Apáczai Közalapítvány: http://www.apalap.hu/letoltes/kutatas/karrierutak_vagy_zarojelentes.pdfpp. 132-172. (Downloded:15.02.2008.)

Gábrity Molnár I., 2008a.-“Vajdaság népességmozgása az utóbbi fél évszázadban”. KözépEurópai Közlemények.vol.1. n², pp 74-85.

Gábrity Molnár I., 2008b-“A szerbiai emigráció fél évszázada. „Határtalan határok” jubileumi Nemzetközi Földrajzi Konferencia, Dobogókő. http://gabritymolnariren.com/emigracio.pdf (Downloded: 15.11.2009.)

Gábrity Molnár I., 2008c -Oktatásunk látlelete. Fórum Könyvkiadó, Újvidék és Újvidéki Egyetem, Magyar Tannyelvű Tanítóképző Kar, Újvidék - Szabadka.

Grečić V., 2001. -"Migracije sa prostora SR Jugoslavije od početka 90-tih godina XX veka. Ekonomski anali.vol.44. n¹53-154, pp 57-84. 
Gredelj S., 2006.--"Virtuelni povratak „četvrte“ i „pete“ generacije migranata. Filozofija $i$ društvo. $\mathrm{n}^{\circ} 29$, pp 77-88.

Korhecz, T. Ifj., 2009. -Otthonteremtőben a szülöföldön. Jogi és politikai esszék. Forum, Újvidék.

L. Rédei M., 2009. - A tanulmányi célú mozgás. Reg-Info Kft. Budapest.

Langer J., 2001. -“A határ új jelentése Közép-Európában”. In Éger Gy. and Langer J. (eds.)Határ, régió, etnikumok Közép-Európában.MTA Kisebbségkutató Intézet,Budapest, pp. 74-92.

Mežnarič S., 2003. -"Migracijske aktuelnosti: stanje, problemi, perspektive paradigmi istraživanja. Migracijske i etničke teme. $\mathrm{n}^{\circ} 4$, pp 323-341.

Mihailović S., 2004.-“'Oduzimanje budućnosti - Omladina Srbije u vodama tranzicije“. In Srećko M. (eds.)Mladi zagubljeni u tranziciji. Centar za proučavanje alternativa, Beograd, pp. 17-37.

Nađ I., 2006. -"Nekoliko obeležja migracije vojvođanske elite“. Zbornik Matice srpske za društvene nauke. $\mathrm{n}^{\circ} 121$, pp 445-456.

Pál Á., 2003.-Dél-Alföldi határvidékek. A magyar-szerb-román határ menti települések társadalom- és gazdaságföldrajzi vizsgálata.PTE TKFI, SZTE JGYTF, Bornus Nyomda, Pécs.

Penev G., Bobić M., Đurđev B.S., Radivojević B., 2007.-“Strukture stanovništva". InĐurđev B.S. (eds.) Stanovništvo i domaćinstva Autonomne Pokrajine Vojvodine početkom XXI. veka.RS, APV, Izvršno Veće APV, Pokrajinski sekretarijat za demografiju, porodicu i društvenu brigu o deci,Novi Sad, pp. 103-180.

Statisztikai adatbázis: Educatio Kht. Budapest, Magyarország, 2011.

Statisztikai adatbázis: KSH Központi Statisztikai Hivatal, Magyarország. 2011.

Statisztikai adatbázis: Nemzeti Erőforrás Minisztérium, Magyarország, 2011.

Statisztikai adatbázis: APV Pokrajinski sekretarijat za obrazovanje, Vojvodina - Srbija, 2011.

Statisztikai adatbázis: Republički zavod za statistiku, Srbija, 2011.

T. Mirnics Zs., 2001.-“Hazától hazáig. A Vajdaságban és Magyarországon tanuló vajdasági magyar egyetemi hallgatók életkilátásai és migrációs szándékai.” InGábrity Molnár I. and Mirnics Zs. (eds.) Fészekhagyó vajdaságiak. Magyarságkutató Tudományos Társaság, Szabadka, pp. 162-204.

Takács Z., 2008. -“A felsőoktatás regionális dimenziói a Vajdaságban”. In Buday-S.A. and Zemplényiné B.J. (eds)A Pécsi Tudományegyetem Regionális politika és gazdaságtan Doktori Iskolájának Évkönyve. PTE KTK, Pécs, pp. 271-283.

Takács Z., 2009. -“Egyetemalapítási helyzetkép a Délvidéken”. InKötél E. and Szarka L. (eds.)Határhelyzetek II. Kultúra - Oktatás - Nyelv - Politika. Balassi Intézet Márton Áron Szakkollégium, Budapest, pp. 289-313.

Takač Z., Kinčes A., 2010 - "Migracija stanovništva iz Republike Srbije u susednu Mađarsku u razdoblju pre Šngenskog sporazuma". Anali Ekonomskog Fakulteta u Subotici. Vol 46. $\mathrm{n}^{\circ} 24$. pp 69-82.

Tóth Pál P., 2001.-“Jugoszláviából Magyarországra”. In Gábrity Molnár I. and Mirnics Zs. (eds.) Fészekhagyó vajdaságiak. Magyarságkutató Tudományos Társaság, Szabadka, pp. 251-269. 